\title{
An Investigation of Willingness to Communication in ESL Classroom: A Quantitative Study of Elementary Students in Pakistan
}

\author{
Jan Muhammad Kalyar ${ }^{1}$, Habibullah Pathan ${ }^{1}$, Mansoor Ahmed Channa ${ }^{2}$, Shoukat Ali Lohar ${ }^{1} \&$ Jam Khan \\ Muhammad $^{1}$ \\ ${ }^{1}$ Mehran University of Engineering and Technology, Jamshoro, Pakistan \\ ${ }^{2}$ Quaid-e-Awam University of Engineering, Science, and Technology, Nawabshah, Pakistan \\ Correspondence: Jan Muhammad Kalyar, Mehran University of Engineering and Technology, Jamshoro, Pakistan. \\ E-mail: kalyar.jan@gmail.com
}

Received: August 30, 2018 Accepted: October 5, 2018 Online Published: December 29, 2018

doi:10.5539/ijel.v9n1p357 URL: https://doi.org/10.5539/ijel.v9n1p357

\begin{abstract}
This study investigates willingness to Communicate (WTC) in ESL classroom of elementary students of higher Secondary School Qazi Ahmed, Pakistan. This current study used close ended questionnaire, adopted from McCroskey (1992). The participants of the study belong to the higher Secondary School Qazi Ahmed. The current study has 300 participant from different grades like 100 learners from six grade, 100 from seven grades, and 100 participants belong to eight grades. These participants were all between 11 year to 15 years of age. The data was analyzed through SPSS version 20 (statistical for social science) in order to find out the ratio and percentage of learners' willingness to communication. The results revealed that a learner learns target language because he/she has to communicate with target community for different purposes. This study finds out the individual differences of learners' willingness to communication (WTC) which is a basically free will for communication that promotes to the integrative motivation and some time, it prefers instrumental motivation to be used.
\end{abstract}

Keywords: WTC, ESL classroom, task-based, unwillingness

\section{Introduction}

The language plays a pivotal role in human's life. Without communication or lacking proper communication always led the individuals to a colorless and absurd life and in results, people or learners can face difficulties or failures at every turn of their lives. Chomsky and Halle (1968) suggested that the 'language is an inborn quality of human being; it is inbuilt and hard-wired in humans' brain. A child can easily acquire all grammatical and syntactical complexities and he can fluently speak in native language (L1). Further, a child can acquire all complexities of language and can speak his/her L1 fluently by making no any grammatical and syntactical error as reported in Chomsky's, (2002) theory of Language acquisition device (LAD). Lieberman (1984), stated that a child born with an ability of linguistic grammar. This ability is called as a universal grammar (Glackin, 2011). Brown (2000) stated that learners start to learn ESL or EFL based on second language acquisition theories "LAD" which can be varied due to diverse age limit, atmosphere, and factors that affect learners' ability of communication in ESL.

\section{Background of the Study}

According to acquisition theories, it is suggested that adults do not successfully acquire or learn any language; because, language learning ability is directly linked with the biological age factors. However, their language ability is affected through internal as well as external factors of society. According to Al Shalabi (2003), the acquisition theories for learning ESL and EFL in communication competence depend upon learners' personal willingness and unwillingness of communication in a target language(Zarrinabadi, 2014). McCrosky (1992) suggested that a learner is not ready to initiate communication or avoiding communication with others. However, learners' traits of personality are called unwillingness to communicate (Fukuta, 2017). According to MacIntyre (2007), L2 learners are unwilling to communication due to various reasons that include personality, individual, social, contextual, situational, attitudinal, motivational, and linguistic incompetency. According to Hashimoto (2002), willingness to Communicate (WTC) can be defined as the degree in which learners are voluntarily ready 
to initiate communication when the learners have personal choice. The willingness to communicate is mainly enriched with the communicative competence (Richmond \& McCroskey, 2012). A learner learns target language because he/she has needed to communicate with target community for different purposes. This study finds out the individual differences of learners' willingness to communication (WTC) which is a basically free will for communication that promotes to the integrative motivation and some time, it prefers instrumental motivation to be used. According to Crystal (2012), English is the global language; because, the English ruled over the world for decades. English is utilized in several international newspapers, magazines, television programs and series, the anchor persons and actors, politicians, businessmen, sportsmen, educationist, and professionals to address their viewpoints in English language; because, they have found maximum audiences to listen them. Audiences prefer those international newspapers, magazines, and books. Those are written in English language which prefers all those international television programs that have English language. They believe that the mentioned sources provided them authentic and universal themes which were globally accepted.

\subsection{English Communication and Pakistan}

After separation of sub-continent, Pakistan came in to being; it consists of five provinces including Sindh, Punjab, Baluchistan, KPK, and Gilgit Baltistan. All provinces have their own language along with some other regional languages spoken. According to Pathan (2012), Pakistan has total 77 regional languages and 27 are more influential. According to Rahman (1990), English is enjoying as official status from sub-continent to date; Urdu is the national language of Pakistan and the controversy of language is still going on into Pakistan. According to Rahman (1991), the government of Pakistan uses English as an official language in most provinces and in higher educational institutes; some private elite institutes also use English as their medium of instruction. From year of establishing of Pakistan to date, English is dominant and remains at high demand for Pakistani students, parents and officials. English is a key of success in competent exams like CSS exam, PCS exam, and even in Military services as cited in Rahman (2014). According to Rahman (2013), almost 11\% Pakistani population speaks English out of 180 million; it indicates Pakistan as the third largest English speaking country in the Asia. In Pakistan, teachers prefer British English and American English variety; while, they have given less preference to local variety of English like PakEnglish. Kachru (2005) supported local English in his most of research. He said that each variety of English has specific purpose at specific cultural context and domain. Kachru suggested that the different domains and cultural context face different certain feature of English language so that he had supported to varieties of English in sub-continent. According to Kachru (1992), learners and speakers willingness will be affected due to emphasis of native like accent. People become nervous and hesitated due to non-native accent which could not match with native like accent. Most of teachers prefer native like accent which were exactly match with British and American accent. Rahman (2014) prefers Pakistani accent because everyone has own cultural domination and cultural influence. Based on these influential forces, speakers are unable to speak in non-native language accent in his atmosphere; these speakers can produce new variety of English language which is called PakEnglish. The language production in the light of Kachru (1992) and Rahman (2014) indicates that Pakistani teachers should support students with this new variety of English according to their cultural domain. The acceptance of cultural deviation of new English variety of student by teachers will increase the learner's willingness to communicate in English language.

\section{Literature Review}

Basically WTC (willingness to communication) construct was originally coined out from unwillingness to communicate. The unwillingness to communicate term was originated by Burgoon and Jones (1976) that some speakers avoid from speaking with the other participants due to bundle of factors which influence or pay hindrance on him/her from speaking, even in their native language. These varieties of factors are anxiety, nervousness, and hostility. Burgoon and Jones (1976, p. 60) suggested that unwillingness to communication is "the unceasing trend of speaker to avoid or devalue the oral communication". They both suggested first time WTC construct (willingness to communication) is the tendency of individual speaker to engage himself in communication with particular partner at specific situation with free will to speak with him/her.

Modern Language pedagogy has given more importance to communicative competence among second language learners. The educators give more emphasis on communicative language teaching and communicative interaction among learners into classroom. According to Canale and Swain (1980), if the educators want to promote communicative language teaching then it may create real world and authentic situation for the learners into the classroom atmosphere which suggest them meaningful task for interaction into the classroom with the target language speaking competency. The authentic real world situation increases learners' willingness to speak into specific context with their classmates. According to MacIntyre (2007), the primary function of L2 study is that the learner furnishes the ability of communication and increases the level of L2 WTC through different facilities 
and drills which would be provided by the facilitators. Communication is an important agent of language survival in the world. MacIntyre (2007) argues that willingness to speak in second language using an authentic communication in target situation which reflects the success in language learning program. If the learners are unable to speak in language learning program then the program will consider it as a failure and unsuccessful. It is the most immediate responsibility and duty of guides and facilitators to create and increase the L2 WTC level among L2 learners. If his/her students are able to speak in target language then it is considered as successful guide. If his/her students are unable to speak then the program as well as guide is considered failure. So, the gist of second language learning depends on communication which would trigger out with the help of WTC construct.

According to Xie (2011), the high level of willingness to speak shows that the high level of speaking and low level of WTC shows low level of speaking. According to Maoz and Ellis (2008), L2 researcher agrees that those students who have possessed more WTC, they are more active in speaking and if the learners have lack of WTC, s/he has less communicative competency. However, higher WTC levels of students can easily create an opportunity to speak in target language and the learners who have less amount of L2 WTC. They are avoiding from communication in target language and usually lose the opportunity.

MacIntyre and Gardner (1991) argue that WTC is necessary for L2 educationists and it is basic construct for language course. Educators should be careful when they prepare the language course. The course may be designed according to the level of student's willingness to communicate; because, language programs success depends upon learner's willingness to speak.So, it is necessary to judge learners' L2 WTC level before designing the language course.

According to Azar and Molavi (2013), WTC model has two types of factors which affect the learner's willingness to communicate in target language and both are different from each other. One is individual difference and other is situational factors. Individual difference concerned with learners personality aspects and second is situational factors which depend on environment and specific situation and learners have choice to speak with specific person at specific time.

According to Tousi and Khalaji (2014), if the educators want to increase the learners' willingness to speak in target language then it may understand variables which affect the learners' willingness to speak these variables will increase and decrees the learners' willingness to speak in target language. So, due to that fact of WTC variables, it is duty of designers to investigate the target learners' WTC variables before designing courses after complete investigation; the language course may also be designed according to WTC variables of target learners. After, some well-known English language teaching (ELT) situation in Pakistan and especially in Sindh, the following section would initiate the introduction of ELT in Pakistan. This study is undertaken to investigate the level of WTC of rural elementary learners in Sindh during class participation.

\section{Research Methodology and Data Analysis}

This current study used close ended questionnaire, adopted from McCroskey (1992). The research measures are taken from communication research measures based on WTC questionnaire. The participants of the study belong to the higher Secondary School Qazi Ahmed. The current study has 300 participant from different grades like 100 learners from six grade, 100 from seven grades, and 100 participants belong to eight grades. These all participants were from 11 year to 15 years of age. The data was collected through closed ended questionnaire. The researcher entered data into SPSS version 20 (statistical for social science) in order to find out the ratio and percentage of learners' willingness to communication. Researcher used MS excel as it is easy to be utilized; the MS excel data was applied in SPSS by coding and using likert scale point from descending to ascending method. The descending option of likert scale point applied in SPSS is almost never willing-1(ANW), sometime willing $=2(\mathrm{STW})$, half of time willing $=3(\mathrm{HTW})$, usually willing $=4(\mathrm{UW})$, and almost always willing=5(AAW).

\section{Findings of the Study}

This study presented results through frequency and percentage by tables and graphic description.

Table 1. Frequency and percentage

\begin{tabular}{|c|c|c|c|c|c|}
\hline \multicolumn{6}{|c|}{ I say "thank you" when my class fellow friends lend me a pen. } \\
\hline & & Frequency & Percent & Valid Percent & Cumulative Percent \\
\hline \multirow[t]{3}{*}{ Valid } & ANW & 2 & .7 & .7 & .7 \\
\hline & STW & 34 & 11.3 & 11.3 & 12.0 \\
\hline & HTW & 54 & 18.0 & 18.0 & 30.0 \\
\hline
\end{tabular}




\begin{tabular}{lllll}
\hline UW & 128 & 42.7 & 42.7 & 72.7 \\
AAW & 82 & 27.3 & 27.3 & 100.0 \\
Total & 300 & 100.0 & 100.0 & \\
\hline
\end{tabular}

According to the above table, the item number five has the highest frequency and item 4 with likert scales indicate "UW" which shows usually willing.The question number five has maximum frequency with 128 on fourth likert scale on "UW" and its total highest percentage is 42.7 and is "UW". It clearly shows frequency graph no. 5.1 that UW graph has maximum between all likert scales and minimum frequency of question five has only 2 and his minimum percentage is .7. These both minimum frequencies and percentage have taken by "ANW". Similarly, the table shows $3.85 \%$ mean and $.973 \%$ standard deviation of question number five. It means that maximum $42.7 \%$ of learners usually willing to say thank you when they had get the pen from their class fellows.

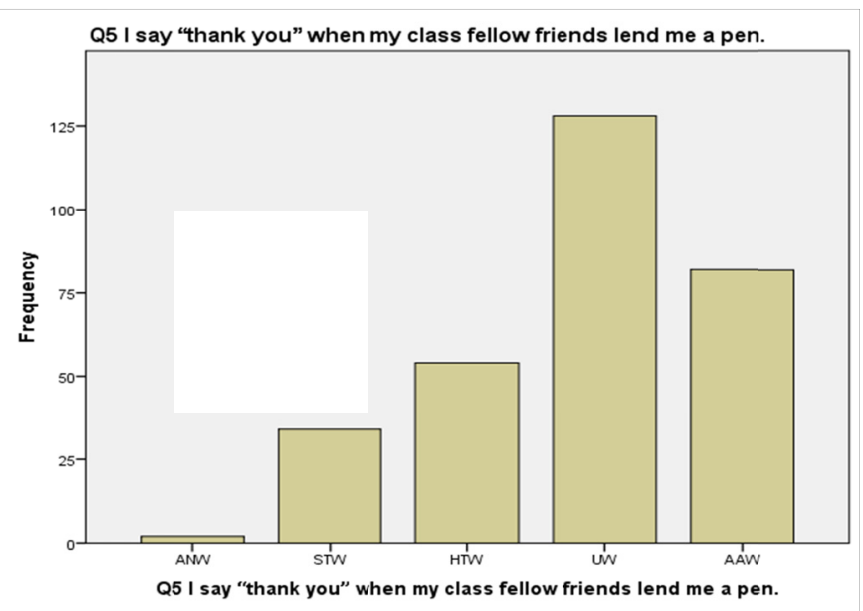

Figure 1. Mentioning about question 5

According to table 2 the second highest items is Q16 in first research question which is set to investigate the learner's willingness to communication in English as a second language.

Table 2. Frequency and percentage

\begin{tabular}{|c|c|c|c|c|c|}
\hline \multicolumn{6}{|c|}{ Q16 I discus in English when my teacher assigns me a peer task. } \\
\hline & & Frequency & Percent & Valid Percent & Cumulative Percent \\
\hline \multirow[t]{6}{*}{ Valid } & ANW & 10 & 3.3 & 3.3 & 3.3 \\
\hline & STW & 54 & 18.0 & 18.0 & 21.3 \\
\hline & HTW & 62 & 20.7 & 20.7 & 42.0 \\
\hline & UW & 112 & 37.3 & 37.3 & 79.3 \\
\hline & AAW & 62 & 20.7 & 20.7 & 100.0 \\
\hline & Total & 300 & 100.0 & 100.0 & \\
\hline
\end{tabular}

According to the above given frequency and percentage in table 2, the participants prefer $37.3 \%$ usually willing to communicate and discuss in English when their teachers assign peer task. According to table 2, the highest frequency is 112 and highest percentage is $37.3 \%$, while minimum frequency is 10 and percentage is $3.3 \%$; it shows "ANW" means the learners are almost never willing to communicate with their peers when teachers assign them a peer task. According to table 2, the item no 16 shows $3.54 \%$ mean, with $1.107 \%$ standard deviation. 




Figure 2. Mentioning about question 16

According to the above, the third highest item is Q 03 in first research question which is set to investigate the learners' willingness to communication in English as a second language. According to the above table, the item no. 03 has $3.24 \%$ mean and its standard deviation is $1.309 \%$. The percentage and frequency are given below in table 3 .

Table 3. Frequency and percentage

\begin{tabular}{|c|c|c|c|c|c|}
\hline \multicolumn{6}{|c|}{ Q3 I greet in English to my teacher when he enters into classroom. } \\
\hline & & Frequency & Percent & Valid Percent & Cumulative Percent \\
\hline \multirow[t]{6}{*}{ Valid } & ANW & 32 & 10.7 & 10.7 & 10.7 \\
\hline & STW & 68 & 22.7 & 22.7 & 33.3 \\
\hline & HTW & 62 & 20.7 & 20.7 & 54.0 \\
\hline & UW & 73 & 24.3 & 24.3 & 78.3 \\
\hline & AAW & 65 & 21.7 & 21.7 & 100.0 \\
\hline & Total & 300 & 100.0 & 100.0 & \\
\hline
\end{tabular}

According to the table, the learners say greeting to their teacher when s/he enters the classrooms. Its response is given by participants as usually willing with $24.3 \%$ and it is the highest percentage in item number 03 . The lowest percentage of item number three is $10.7 \%$ which shows that learners are almost never willing to say greeting to their teachers when $\mathrm{s} /$ he enters the classroom. Above given frequency and percentage also shown in below bar graphic table 3 . 


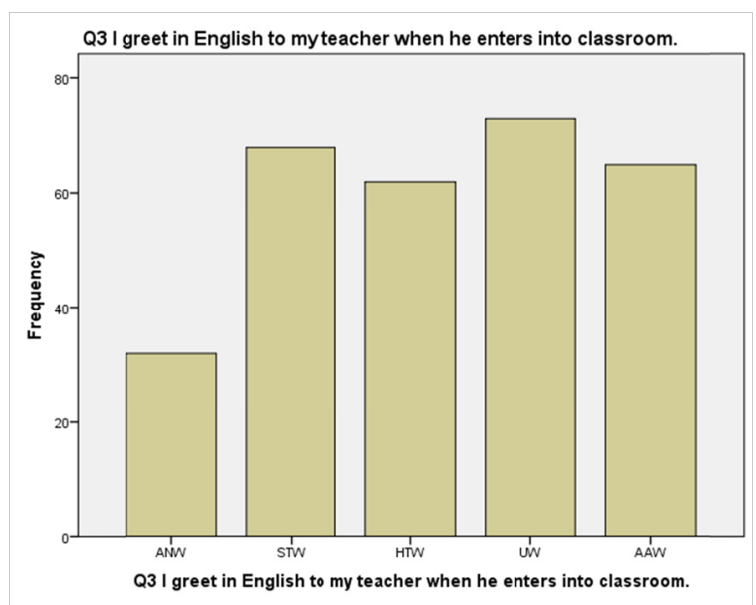

Figure 3. Mentioning about question 3

According to the above table, the fourth highest item is Q 01 in first research question which is set to investigate the learners' willingness to communication in English as a second language. The item 01 states that the learners were introduced in front of classmates. According to table that the item 01 has $3.17 \%$ mean and its standard deviation is $1.191 \%$ and the frequency is given below into table 4 .

Table 4. Frequency and percentage

\begin{tabular}{llllll}
\hline \multicolumn{2}{l}{ Q1 I introduce myself in English in front of classmates. } & & \\
& & Frequency & Percent & Valid Percent & Cumulative Percent \\
\hline Valid & ANW & 31 & 10.3 & 10.3 & 10.3 \\
& STW & 58 & 19.3 & 19.3 & 29.7 \\
& HTW & 80 & 26.7 & 26.7 & 56.3 \\
UW & 91 & 30.3 & 30.3 & 86.7 \\
& AAW & 40 & 13.3 & 13.3 & 100.0 \\
& Total & 300 & 100.0 & 100.0 & \\
\hline
\end{tabular}

According to frequency and percentage as mentioned in table4, almost 91 out of 300 participants were usually willing to introduce himself in English language in front of their classmates; this is the highest percentage with $30.3 \%$, while 31 participant out of 300 are always never willing to introduce himself in English language in front of classmates and their minimum percentage is $10.3 \%$. However, the bar graphic presented the frequency and percentage diagram. The highest bar graph shows the highest percentage; while, short bar shows lowest percent.



Figure 4. Mentioning about question 1 
According to the above table, the second lowest item is Q 09 of first research question which is set to investigate the learners' willingness to communication in English as a second language. The item number nine states that the learners were inquiring of their teachers about English language sentence structure in English language. The above tablesuggested that the mean of items number nine is $3.10 \%$; while, the standard deviation of item numbers nine is 1.312. The frequency and percentage is given below in table5.

Table 5. Frequency and percentage

\begin{tabular}{|c|c|c|c|c|c|}
\hline \multicolumn{6}{|c|}{ Q9 I ask my teacher in English to give examples about sentence structures in English. } \\
\hline & & Frequency & Percent & Valid Percent & Cumulative Percent \\
\hline \multirow[t]{6}{*}{ Valid } & ANW & 40 & 13.3 & 13.3 & 13.3 \\
\hline & STW & 71 & 23.7 & 23.7 & 37.0 \\
\hline & HTW & 61 & 20.3 & 20.3 & 57.3 \\
\hline & UW & 75 & 25.0 & 25.0 & 82.3 \\
\hline & AAW & 53 & 17.7 & 17.7 & 100.0 \\
\hline & Total & 300 & 100.0 & 100.0 & \\
\hline
\end{tabular}

According to frequency and percentage, table 5 shows that students with $20.3 \%$ are usually willing to ask teacher for sentence structure in English language; while, 13.3\% are almost never willing to ask teacher for sentence structure in English language. The same frequency and percentage are given into bar graphic version. The Bar graphic version and item number nine is given bellow it shows that the learner willingness to communication through bar graph in bar graph table 5 .

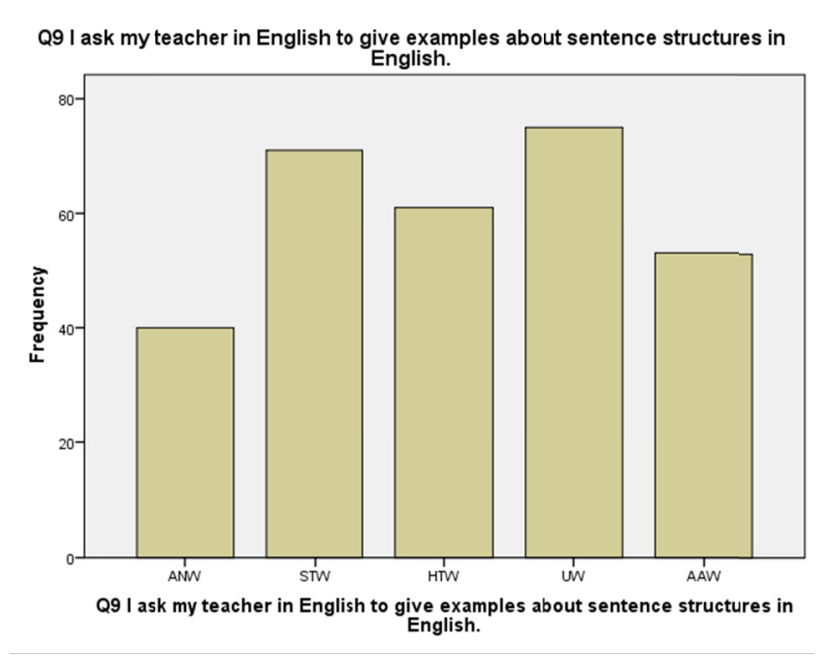

Figure 5. Mentioning about question 9

According to the below table, the lowest item of Q 08 in first research question is set for investigating the learners' willingness to communication in English as a second language. The item number eight states that the learners are asking from their class fellow about the English words pronunciation in English language. The table 6 suggested that the mean of item number eight is $3.02 \%$; while, the standard deviations of item number eight is 1.260. The frequency and percentage are given below in table 6 which states the frequency and percentage of item number eight. The table shows that the maximum percentage taken by "STW" some time willing which is $29.3 \%$; while, minimum percentage taken by "ANW" Almost never willing is $11 \%$. According to likert scale, the ANW and STW are counted as disagree. 
Table 6. Frequency and percentage

\begin{tabular}{|c|c|c|c|c|c|}
\hline \multicolumn{6}{|c|}{ Q8 I ask my class fellow in English about pronunciation of the English words } \\
\hline & & Frequency & Percent & Valid Percent & Cumulative Percen \\
\hline \multirow[t]{6}{*}{ Valid } & ANW & 33 & 11.0 & 11.0 & 11.0 \\
\hline & STW & 88 & 29.3 & 29.3 & 40.3 \\
\hline & HTW & 66 & 22.0 & 22.0 & 62.3 \\
\hline & UW & 69 & 23.0 & 23.0 & 85.3 \\
\hline & AAW & 44 & 14.7 & 14.7 & 100.0 \\
\hline & Total & 300 & 100.0 & 100.0 & 100.0 \\
\hline
\end{tabular}

According to the frequency and percentage in the above table, almost $29.3 \%$ students are "STW" that means students are unwilling to ask accurate pronunciation of an English words in English language; while, 23.0\% students are willing to ask pronunciation of English words from their class fellows. Similarly, the graphic frequency and percentage of table 6 is given below in bar graphic shape.

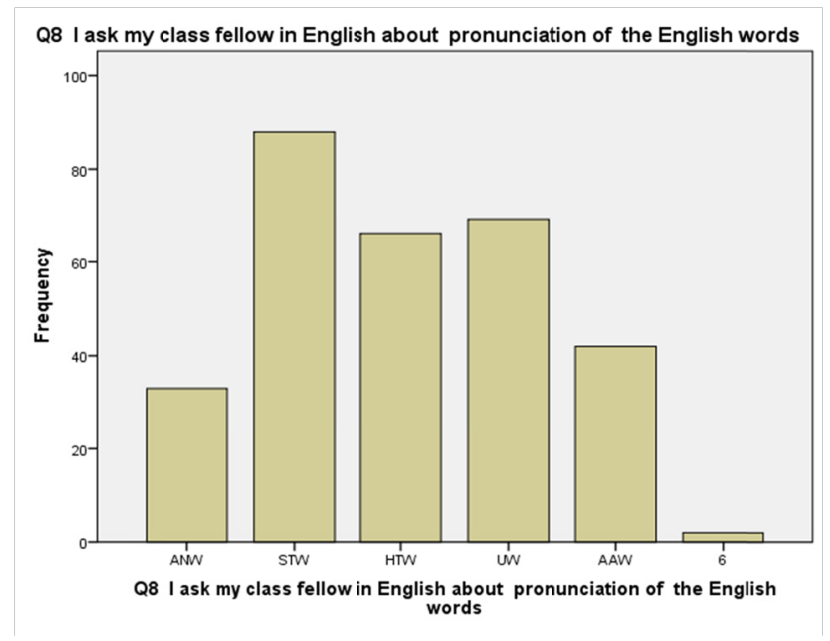

Figure 6. Mentioning about question 8

\section{Discussion and Conclusion}

The first research question mentioned above illustrates that the Sindhi rural elementary learners have low level of WTC to communicate in L2. The findings of current study were coordinated with previous research findings which were conducted within second language learning countries especially in Asian countries. According to Xie (2011), the selected chine's rural secondary students had low level of WTC. According to Baghaei (2013), ESL learners did not achieve L1 learners' proficiency because they did not find L1 classroom atmosphere which means classroom arrangement and teachers' fluency along with learners' engagement were influenced on learners' personality. The performance of L2 learners have same and accurate L1 classroom atmosphere in which all learners achieve exact and accurate L1 like performance and language proficiency otherwise it is impossible. The reason of low level of L2 proficiency is due to learners' personality traits as well as socio-cultural affects. To conclude, this study aimed to research the factors that influence the learners' willingness to communication in English as a L2 at elementary level in rural Sindh mainly at government higher secondary school Kazi Ahmed. This study indicates the level of willingness to communication of elementary learner and rural elementary English language teacher during class activity. This study also showed that the percentage and ratio of learners and teachers' willingness to communicate in ESL class room during class activities.

\section{References}

Al Shalabi, M. F. (2003). Study of theories of personality and learning styles; some implications and sample activities to support curriculum change in a higher education TESOL program in Syria. Moray House School of Education, the University of Edinburgh.

Azar, A. S., \& Molavi, S. (2013). Iranian EFL Learners' Attitudes toward Correction of Oral Errors. The European 
$\begin{array}{llllll}\text { Journal of Social } \quad \& \quad \text { Behavioral } & \text { Sciences, } & 4(1), & 801 .\end{array}$ https://doi.org/10.15405/FutureAcademy/ejsbs(2301-2218).2012.4.13

Baghaei, P. (2013). Development and psychometric evaluation of a multidimensional scale of willingness to communicate in a foreign language. European Journal of Psychology of Education, 28(3), 1087-1103. https://doi.org/10.1007/s10212-012-0157-y

Brown, H. D. (2000). Principles of language learning and teaching. (4th ed.). New York: Longman. (pp. 152-165)

Burgoon, J. K., \& Jones, S. B. (1976).Toward a theory of personal space expectations and their violations. Human Communication Research, 2(2), 131-146. https://doi.org/10.1111/j.1468-2958.1976.tb00706.x

Canale, M., \& Swain, M. (1980). Theoretical bases of com-municative approaches to second language teaching and testing. Applied Linguistics, 1(1), 1-47.https://doi.org/10.1093/applin/1.1.1

Chomsky, N. (2002). On nature and language. Cambridge University Press. https://doi.org/10.1017/CBO9780511613876

Chomsky, N., \& Halle, M. (1968).The sound pattern of English. Harper \& Row, Publishers, Incorporated, 49 East 33rd Street, New York, N.Y. 10016.

Crystal, D. (2012). English as a global language. Cambridge university press. https://doi.org/10.1017/CBO9781139196970

Fukuta, J. (2017). Psychological Attributes of Unwillingness to Communicate and Task-Based Instruction. TESL-EJ, 21(3).

Glackin, S. N. (2011). Universal grammar and the Baldwin effect: a hypothesis and some philosophical consequences. Biology \& Philosophy, 26(2), 201-222. https://doi.org/10.1007/s10539-010-9225-3

Hashimoto, Y. (2002). Motivation and willingness to communicate as predictors of reported L2 use: The Japanese ESL context. Second Language Studies, 20(2), 29-70.

Kachru, B. B. (1992). World Englishes: Approaches, issues and resources. Language Teaching, 25(1), 1-14. https://doi.org/10.1017/S0261444800006583

Kachru, B. B. (2005). Asian Englishes: beyond the canon (Vol. 1). Hong Kong University Press.

Lieberman, P. (1984). The biology and evolution of language. Harvard University Press.

MacIntyre, P. D. (2007). Willingness to communicate in the second language: Understanding the decision to speak as a volitional process. The Modern Language Journal, 91(4), 564-576. https://doi.org/10.1111/j.1540-4781.2007.00623.x

MacIntyre, P. D. \& Gardner, R. C. (1991). Investigating language class anxiety using the focused essay $\begin{array}{lllll}\text { technique. The } & \text { 296-304. }\end{array}$ https://doi.org/10.1111/j.1540-4781.1991.tb05358.x

Maoz, I., \& Ellis, D. G. (2008). Intergroup communication as a predictor of Jewish-Israeli agreement with integrative solutions to the Israeli-Palestinian conflict: The mediating effects of out-group trust and guilt. Journal of Communication, 58(3), 490-507. https://doi.org/10.1111/j.1460-2466.2008.00396.x

McCroskey, J. C. (1992). Reliability and validity of the willingness to communicate scale.Communication Quarterly, 40(1), 16-25. https://doi.org/10.1080/01463379209369817

Pathan, H. (2012). A longitudinal investigation of Pakistani university students' motivation for learning English. Doctoral dissertation, University of Glasgow.

Rahman, T. (1990). Pakistani English. Published by National Institute of Pakistan Studies. Islamabad.

Rahman, T. (1991). Pakistani English: some phonological and phonetic features. World Englishes, 10(1), 83-95. https://doi.org/10.1111/j.1467-971X.1991.tb00139.x

Rahman, T. (2013). Personal Names of Pakistani Muslims: An Essay on Onomastics. Pakistan Perspectives, $18(1), 33-57$.

Rahman, T. (2014). Othering through language. The Other in South Asian Religion, Literature, and Film: Perspectives on Otherism And Otherness, Routledge.

Richmond, V. P., \& McCroskey, J. C. (2012). Power in the classroom: Communication, control, and concern. Routledge. 
Tousi, M., \& Khalaji, H. (2014). The Impact of Willingness to Communicate on Iranian EFL Learners Speaking Ability. International Research Journal of Applied and Basic Sciences, 8(11), 1866-1869.

Xie, Y. (2011). Representations of L2 Motivational Self System with beginning Chinese language learners atcollege level in the United States: Heritage and nonheritage language learners. Unpublished doctoral dissertation, Virginia, Liberty University.

Zarrinabadi, N. (2014). Communicating in a second language: Investigating the effect of teacher on learners' willingness to communicate. System, 42, 288-295. https://doi.org/10.1016/j.system.2013.12.014

\section{Copyrights}

Copyright for this article is retained by the author, with first publication rights granted to the journal.

This is an open-access article distributed under the terms and conditions of the Creative Commons Attribution license (http://creativecommons.org/licenses/by/4.0/). 